14). Rather some factors related to place of birth and early residence, perhaps close cohabitation in poor housing with an index patient, seem to promote HTLV-I infection. Improvement in such conditions was a prime reason for migration; indeed in 1897 the first Jamaican account of a tropical spastic paraparesislike syndrome reported that many cases were found among the poor, as was found later. ${ }^{31} 32$

In conclusion, our data suggest that place of birth and early residence rather than maternal or age effects are the important factors in HTLV-I infection. No evidence of prolonged seronegative incubation of HTLV-I has been found.

We thank the Multiple Sclerosis Society of Great Britain and Northern Ireland for JHR's research fellowship and for supporting this study. JKC received support from the Wellcome Trust.

1 Yoshida M, Miyoshi I, Hinuma Y. Isolation and characterisation of retrovirus from cell lines of human adult $T$-cell leukaemia and its implication in the from cell lines of human adult T-cell leukaemia
disease. Proc Natl Acad Sci USA 1982;79:2031-5.

2 Anonymous. HTLV-1 comes of age [Editorial]. Lancet 1988;i:217-9.

3 Rodgers-Johnson P, Morgan OC, Mora C, et al. The role of HTLV-1 in tropical spastic paraparesis in Jamaica. Ann Neurol 1988;23:121-6.

4 Morgan OC, Montgomery RD, Rodgers-Johnson P. The myelopathies of Jamaica: an unfolding story. $Q \mathcal{F}$ Med 1988;67:273-82.

Catovsky D, Greaves MF, Rose M, et al. Adult T-cell lymphoma-leukaemia in blacks from the West Indies. Lancet 1982;i:639-43.

6 Blattner WA, Nomura A, Clark JW, et al. Modes of transmission and evidence for viral latency from studies of HTLV-I in Japanese migrant populations in Hawaii. Proc Natl Acad Sci USA 1986;83:4895-8.

7 Newton $M$, Cruickshank JK, Miller D, et al. Antibody to human T lymphotropic virus type $I$ in West Indian born UK residents with spastic pamphotropic virus type 1 in

8 Cruickshank JK, Rudge P, Dalgleish AG, et al. Tropical spastic paraparesis and HTLV-1 in the United Kingdom. Brain 1989;112:1057-90.

9 Tokudome S, Tokunaga $\mathrm{O}$, Shimamoto $\mathrm{Y}$, et al. Incidence of adult T-cell leukaemia/lymphoma among HTLV-1 carriers in Saga, Japan. Cancer Res 1989;49:226-8.

10 Murphy EL, Hanchard B, Figueroa JP, et al. Modelling the risk of adult T-cell leukaemia/lymphoma in persons infected with HTLV-1. Int $\mathcal{J}$ Cancer 1989;43:250-3.

11 Kondo T, Kono H, Miyamoto N, et al. Age and sex-specific cumulative rate and risk of ATLL for HTLV-1 carriers. Int 7 Cancer 1989;43:1061-4.

12 Inaba S, Sato H, Okochi K, et al. Prevention of transmission of HTLV-1 through transfusion, by donor screening with antibody to the virus. Transfusion 1989;7:1-11.

13 Kusuhara K, Sonoda S, Takahashi K, et al. Mother-to-child transmission of
HTLV-1: a fifteen-year follow-up study in Okinawa, Japan. Int $\mathcal{F}$ Cancer 1987;40:755-7.

4 Ka)iyama W, Kashiwagi S, Ikematsu $\mathrm{H}$, et al. Intrafamilial transmission of adult T-cell leukaemia virus. I Infect Dis 1986;154:851-7.

15 Miller GJ, Pegram SM, Kirkwood BR, et al. Ethnic composition, age and sex, together with location and standard of housing as determinants of HTLV 1 infection in an an

16 Marmot MG. General approaches to migrant sudies: the relions disease, sociol the relation between disease, social class and ethnic origin. In: Cruickshank JK, Beevers DG 1989.

17 Dalgleish AG, Richardson JH, Matutes E, et al. HTLV-1 infection in TSP: lymphocyte culture and serological response. AIDS and Human Retroviruses $1988: 4: 475-85$

18 Sinclair AL, Habeshaw JA, Muir L, et al. Antibody-dependent cell-mediated cytotoxicity: comparison between HTLV-1 and HIV assays. AIDS 1988;2: 465-7

19 Madisen L, Hoar DI, Holroyd CD, et al. DNA banking: the effects of storage of blood and isolated DNA on the integrity of DNA. Am F Med 1987;27 $379-90$.

19a Richardson JH, Wucherpferrig KW, Endo $\mathrm{N}$, et al. Polymerase chain reaction analysis of DNA from multiple sclerosis patients for the presence of HTLV-I. Science 1989;246:821-3.

20 Hoxie JA, Matthews DM, Clines DB. Infection of human endothelial cells by HTLV-1. Proc Natl Acad Sci USA 1984;81:7591-5.

21 Ho DD, Rota TR, Hirsh MS. Infection of human endothelial cells by HTLV-1. Proc Natl Acad Sci USA 1984;81.23:7588-90.

22 Clapham P, Nagg K, Cheingsong-Popov R, Exley M, Weiss RA. Productive infection and cell-free transmission of HTLV-1 in a non-lymphoid line. Science 1983:222:1125-7.

23 Pate EJ, Wiktor SZ, Murphy EL, et al. Maternal-infant transmission of HTLV-1 in Jamaica. West Indian Med f 1989;38 (suppl 1):34

24 Hino S, Yamaguchi K, Katamine S, et al. Mother-to-child transmission of human T-cell leukaemia virus type-1. fapanese foumal of Cancer Research (Gann) 1985;76:474-80.

25 Kinoshita K, Hino S, Amagasaki T, et al. Demonstration of adult T-cell leukaemia antigen in milk from three seropositive mothers. Fapanese fournal of Cancer Res (Gann) 1984;75:103-5.

26 Hirose S, Kotani S, Uemura Y, et al. Milk-borne transmission of human Tcell leukaemia virus type 1 in rabbits. Virology 1988;162:487-9.

27 Tajima K, Kamura S, Ito $M$, et al. Epidemiological features of HTLV- 1 carriers and incidence of ATL in an ATL-endemic island: a repor of the community-based co-operative study in Tsushima, Japan. Int $\mathcal{Y}$ Cancer 1987;40:741-6.

28 Murphy EL, Figueroa JP, Gibbs WN, et al. Sexual transmission of HTLV-1. Ann Intern Med 1989;111:555-60.

29 Tedder RS, Shauson DC, Jeffries DJ, et al. Low prevalence in the UK of HTLV-1 and HTLV-2 infection in subjects with extended lymphadenoHTLV-1 and HTLV-2 infection in subjects with
pathy and at risk of AIDS. Lancet 1984;ii:125-8.

30 Strachan H. On a form of multiple neuritis in Jamaica. Practitioner 1897;59. 477-8

31 Cruickshank EK. A neuropathic syndrome of uncertain origin: review of 100 cases. West Indian Med $\mathcal{F}$ 1956;5:147-58.

32 Montgomery RD, Cruickshank EK, Robertson WB, McMenemey WH. Clinical and pathological observations on Jamaican neuropathy: a report on 206 cases. Brain 1964;87:425-62.

(Accepted 27 November 1989)

\section{Absorption of glycine irrigating solution during transcervical resection of endometrium}

\section{Ralf Baumann, Adam L Magos, Jonathan D S Kay, Alexander C Turnbull}

Nuffield Department of Obstetrics and

Gynaecology, University of Oxford, John Radcliffe

Hospital, Oxford OX3 9DU

Ralf Baumann, MD, research

fellow in gynaecological

endoscopy

Adam L Magos, MRCOG, clinical lecturer

Sir Alexander C Turnbull,

FRCOG, professor

Nuffield Department of

Clinical Biochemistry,

University of Oxford, John

Radcliffe Hospital

Jonathan D S Kay,

MRCPATH, consultant

chemical pathologist

Correspondence to: $\mathrm{Mr}$

Magos.

BrMed f 1990;300:304-5
We recently described transcervical resection of the endometrium as a less invasive alternative to hysterectomy for menorrhagia.' The operation is similar to transurethral resection of the prostate in terms of technique and the use of liquid media such as $1.5 \%$ glycine solution for distension and irrigation. As absorption of large volumes of such fluid can cause fluid overload, hyponatraemia, cerebral oedema, haemolysis, and even death ${ }^{2}$ we assessed the risk of these complications associated with the operation.

\section{Patients, methods, and results}

We studied 10 women aged 34-51 who were undergoing endometrial resection for symptoms of menorrhagia. They were otherwise healthy, and none took drugs that affected renal function. All women were starved for six hours preoperatively, and intravenous fluids were not used during the operation. The operative technique was as described previously ${ }^{1}$ and included careful monitoring of inflow and outflow of the uterine irrigant. Haemoglobin concentration, packed cell volume, plasma osmolality, lactate dehydrogenase activity (an indicator of haemolysis), and plasma concentrations of sodium, potassium, creatinine, total protein, albumin, and glycine were measured before, during (at 10, 20, and 30 minutes), and after (at two, four, six, and 24 hours) resection.

The mean operating time was $39 \cdot 2$ minutes (range 20-80). Vital signs remained normal in all cases, and the mean estimated blood loss was $133 \mathrm{ml}(80-200)$. A mean of $4948 \mathrm{ml}$ irrigant was infused into the uterus (1750-8900), the mean deficit of fluid at the end of the operation being $643 \mathrm{ml}(100-2030)$. The volume of fluid absorbed was smallest $(100$ and $200 \mathrm{ml})$ in two patients who had been sterilised.

There was a negative linear correlation between the volume of irrigant absorbed and the change in plasma sodium concentration $(\mathrm{r}=-0.717, \mathrm{p}<0.02)$; hyponatraemia of 125 and $130 \mathrm{mmol} / \mathrm{l}$ occurred in two women within 10-30 minutes of the start of the operation, both women having absorbed more than $900 \mathrm{ml}$ of irrigant. Changes in plasma sodium concentration were paralleled by falls in total protein, albumin, and haemoglobin concentrations and packed cell volume, but only minor fluctuations occurred in potassium and creatinine concentrations (table). Lactate dehydrogenase activity increased after the operation in the two women with hyponatraemia. Only two out of nine women monitored showed an increase 


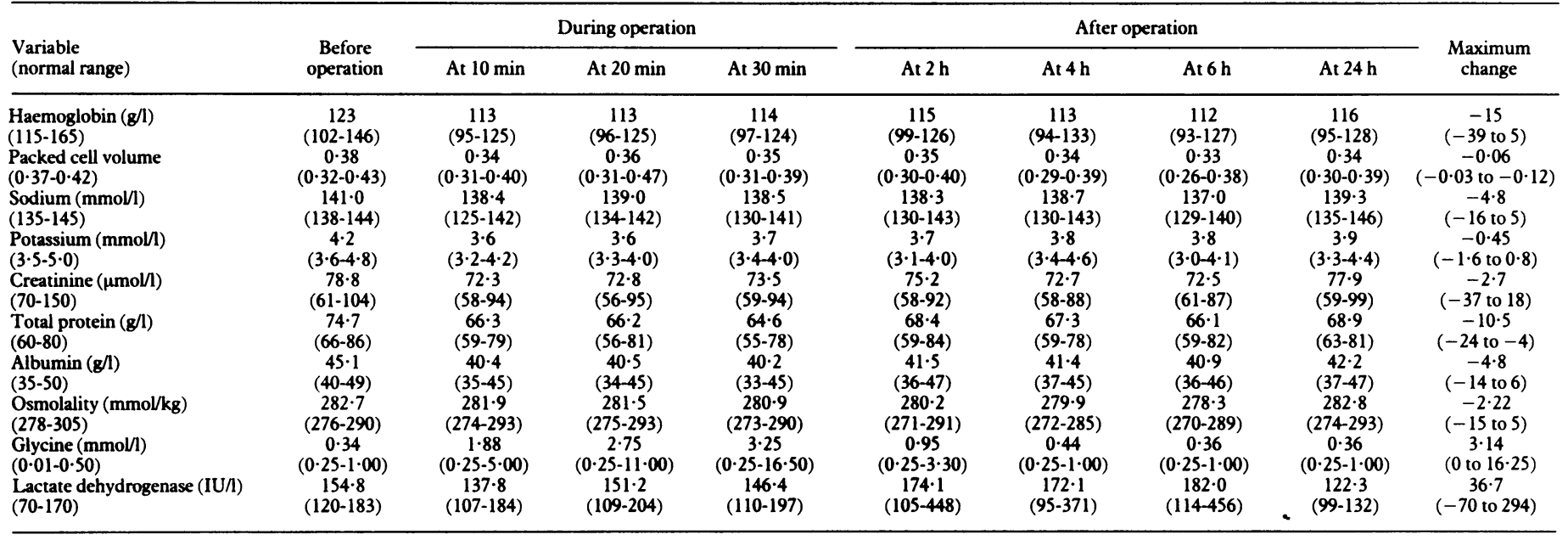

in plasma glycine concentration, peritoneal fluid from one having a glycine concentration of $75 \mathrm{mmol} / \mathrm{l}$. All variables measured returned to baseline values within 24 hours, and no patient had clinical evidence of the transurethral syndrome.

\section{Comment}

Transcervical endometrial resection in which $1.5 \%$ glycine solution is used to distend and irrigate the uterus does carry a risk of fluid overload and rapid dilutional hyponatraemia during the operation. There were no clinical sequelae to these fluid shifts in our study, but recently a woman absorbed $4350 \mathrm{ml}$ of irrigant during the operation and her plasma sodium concentration fell to $117 \mathrm{mmol} / 1$; she responded promptly to diuretics, although the sodium concentration took 24 hours to return to normal.

During the operation some irrigant must infuse into opened myometrial vessels, but, unlike in laser ablation, ${ }^{3}$ transtubal loss and rapid peritoneal absorption also seem to be important in electroresection. Preoperative tubal occlusion may thus be useful in high risk cases.

In summary, fluid balance must be closely monitored during endometrial resection, ideally with a continuous flow instrument. ${ }^{4}$ The main biochemical effect of fluid overload is hyponatraemia, so plasma sodium concentrations should be measured if more than $900 \mathrm{ml}$ of irrigant is absorbed; severe hyponatraemia is unusual unless the fluid deficit is large ( $>2$ litres). In cases that are less severe plasma biochemical variables return to normal spontaneously within 24 hours, which is advantageous if the procedure is done on an outpatient basis. $^{\text {s }}$

We are grateful for the helpful suggestions of $\mathrm{Mr} \mathrm{J} \mathrm{C} \mathrm{Smith,}$ consultant urologist, and Mr M GW Kettlewell, consultant surgeon, at Oxford and for the technical help of Mr Jay Warren. RB was supported by a grant from NHS Locally Organised Research.

1 Magos AL, Baumann R, Turnbull AC. Transcervical resection of endometrium in women with menorrhagia. Br Med $\mathcal{F}$ 1989;298:1209-12.

Rao PN. Fluid absorption during urological endoscopy. $\mathrm{Br} \mathcal{f}$ Urol 1987;60: 93-9.

3 Morrison LMM, Davis J, Sumner D. Absorption of irrigating fluid during laser photocoagulation of the endometrium in the treatment of menorrhagia. Brf Obstet Gynaecol 1989;96:346-52.

4 Iglesias JJ, Sporer A, Gellman AC, Seebode JJ. New Iglesias resectoscope with continuous irrigation, simultaneous suction and low intravesical pressure. continuous irrigation, sim

5 Magos $A L$, Baumann $R$, Cheung $K$, Turnbull AC. Intra-uterine surgery under intravenous sedation as an out-patient alternative to hysterectomy. Lance 1989;ii:925-6.

(Accepted 27 September 1989)

\section{Should radiologists talk to patients?}

\section{Stephen R Vallely, J O Manton Mills}

Increased use of procedures such as angiography, ultrasound, and interventional techniques has resulted in a closer relationship between patients and radiologists. Many radiologists, however, are reluctant to discuss investigations with patients in detail, reasoning that patients are only temporarily in their care. Some clinicians agree with this view on the basis that radiologists do not know all the facts about the patient and are not ultimately responsible for clinical management.

We determined the views of NHS patients, radiologists, and clinicians on what radiologists should discuss with patients about their investigations.

\section{Patients, methods, and results}

We sent a detailed questionnaire to 400 consecutive outpatients attending the radiology department of this hospital for a barium meal examination or barium enema. We also sent a questionnaire to 53 radiologists in Northern Ireland, asking how they communicated with patients attending for barium studies, and to 37 clinicians with an interest in gastroenterology, seeking their views on what radiologists should tell patients. The radiologists and clinicians were invited to reply anonymously.

The response rate was $72 \%(287 / 400)$ for the patients, $62 \%(33 / 53)$ for the radiologists, and $87 \%(32 / 37)$ for the clinicians (of whom 21 were surgeons). The mean age of the patients was 50.1 years (range 18-83), and 147 patients had a barium meal examination and 140 a barium enema.

Altogether 101 patients were men and 186 women. Fears that cancer might be diagnosed were expressed by equal proportions of men and women $(53 \%(53)$ and $52 \%$ (97) respectively). Of 126 patients who had had symptoms for $<12$ months, $58(46 \%)$ were worried they might have cancer. There were 161 patients who had had symptoms $\geqslant 12$ months and of these $86(53 \%)$ were similarly worried. Eight (3\%) were found to have cancer; of these five had been worried about cancer before investigation. Referring clinicians gave a pro- 